https://doi.org/10.52058/2708-7530-2021-6(12)-32-38

Кіпіані Майя Віталіївна аспірант Інституту підготовки кадрів Державної служби зайнятості України, вул. Нововокзальна, 17, Київ, 03038, тел.: (044) 239-07-99, e-mail: naykipk@ukr.net, https://orcid.org/0000-0001$6624-935 \mathrm{X}$

\title{
ОСОБЛИВОСТІ РЕАЛІЗАЦЇ̈ ПУБЛІЧНОЇ ПОЛІТИКИ В УМОВАХ РОЗГОРТАННЯ СУЧАСНОЇ ПАНДЕМІЇ ТА ІІЇ ВПЛИВ НА СУСПІЛЬНИЙ РОЗВИТОК ДЕРЖАВИ
}

\begin{abstract}
Анотація. В межах даної статті розкрито особливості реалізації публічної політики в умовах розгортання сучасної пандемії: зміна традиційного ціннісного укладу функціонування світу; міжнародна мобільність світу; зниження показників економічного розвитку; деконструкція національних систем охорони здоров'я. Показано що в умовах пандемії публічна політика має перетворитись на «своєрідний індикатора якості інституційного середовища» публічної системи зберегти потенційну спроможність інститутів публічної політики належно реагувати на виклики пандемії. Встановлено, що основними вимогами ефективної діяльності інститутів публічної політики $є$ : 1) наявність нормативно-правових актів, які регулюють створення інституту, а також визначають правила, норми i процедури його функціонування; 2) відповідність правозастосовної практики в діяльності інституту визначених нормативно-правовими актами; 3) наявність навченого персоналу, який забезпечує якісну роботу інституту публічної політики і відповідає за дотримання його функцій; 4) розуміння громадянами ролі інституту публічної політики і своєї участі в його діяльності (при оцінюванні). Обгрунтовано, що не лише держава задає моральні та правові імперативи дотримання карантинних умов, але й сам громадянин керуючись відповідною моральною шкалою створює відповідні самообмежувальні запобіжники, які слугують пом'якшення протікання пандемії. У даному відношенні громадяни керуючись своєю ціннісною шкалою оцінюють результативність публічної політики щодо реалізації їх соціально безпекових потреб. У даному відношенні йдеться про формування відповідних «етичних режимів», які індикативні сфері реалізації публічної політики в умовах пандемії. Доведено, що дотримання відповідних вимог результативності реалізації публічної політики дозволяе виявити показники забезпечення сталості суспільного розвитку та індикатори необхідності запровадження інституціонального реформування у системі публічного управління.
\end{abstract}

Ключові слова: публічна політика, публічне управління, квазісуспільні організації, пандемія, Covid-19, протиепідеміологічні заходи, ефективність, система охорони здоров'я. 
Kipiani Maiia Vitaliivna Postgraduate student of the Institute for the Ukrainian state employment service training institute, Novovokzalna St., 17, Kyiv, 03038, tel.: (044) 239-07-99, e-mail: naykipk@ukr.net, https://orcid.org/00000001-6624-935X

\title{
PECULIARITIES OF PUBLIC POLICY IMPLEMENTATION IN THE CONDITIONS OF DEVELOPMENT OF THE MODERN PANDEMIC AND ITS IMPACT ON THE SOCIAL DEVELOPMENT OF THE STATE
}

\begin{abstract}
Within the limits of this article features of realization of public policy in the conditions of development of a modern pandemic are opened: change of a traditional value way of functioning of the world; international mobility of the world; reduction of economic development indicators; deconstruction of national health systems. It is shown that in a pandemic, public policy should become a "kind of indicator of the quality of the institutional environment" of the public system to maintain the potential ability of public policy institutions to respond appropriately to the challenges of a pandemic. It is established that the main requirements for the effective operation of public policy institutions are: 1) the presence of regulations governing the establishment of the institute, as well as determine the rules, regulations and procedures for its operation; 2) compliance of law enforcement practice in the activities of the institute defined by regulations; 3 ) the presence of trained staff that ensures the quality of the work of the institute of public policy and is responsible for compliance with its functions; 4) citizens' understanding of the role of the institute of public policy and their participation in its activities (in evaluation).

It is substantiated that not only the state sets moral and legal imperatives for compliance with quarantine conditions, but also the citizen himself, guided by the appropriate moral scale, creates appropriate self-limiting safeguards that serve to mitigate the pandemic. In this regard, citizens, guided by their value scale, evaluate the effectiveness of public policy to meet their social security needs. In this regard, we are talking about the formation of appropriate "ethical regimes", which are indicative of the implementation of public policy in a pandemic. It is proved that compliance with the relevant requirements for the effectiveness of public policy allows to identify indicators of sustainable social development and indicators of the need for institutional reform in the public administration system.
\end{abstract}

Keywords: public policy, public administration, quasi-public organizations, pandemic, Sovid-19, anti-epidemiological measures, efficiency, health care system.

Постановка проблеми. Аналізуючи особливості реалізації публічної політики в умовах розгортання сучасної пандемії доцільно окрему увагу приділити готовності та інституційній спроможності суб'єктів публічної політики ресурсно реагувати на ризик суспільного розвитку, які зумовлені ризиками негативного впливу пандемії. У даному відношенні йдеться про трансформацію інституційної вертикалі публічної політики у напрямку 
готовності забезпечити відкритість публічного управління у сфері протидії пандемії, забезпечення сталості функціонування сфери охорони здоров'я та ін. В даному відношенні публічна політика в умовах розгортання пандеміі покликана гарантувати налагодження зворотного зв'язку між державою та суспільством, між державою та бізнес середовищем. П̈ї основна результативність полягає у «відпрацюванні дієвості інститутів взаємодії», оскільки вона покликана гарантувати запровадження ефективного інструментарію державі у напрямку протидії пандемії.

Аналіз останніх досліджень і публікацій. В умовах аналізу особливостей реалізації публічної політики в умовах розгортання сучасної пандемії та іï впливу на суспільний розвиток держави окрему увагу варто приділити визначенню результативності механізмів публічного контролю за діяльністю інститутів публічної політики, покликаних забезпечити запровадження антиепідеміологічних заходів. Виходячи із цього результативність реалізації публічної політики в умовах пандемії можна визначити за наступними показниками, серед яких:

а) підтримка громадських ініціатив та функціональна результативність громадських організацій у системі надання якісних медичних послуг;

б) система охорони здоров'я, яка надає якісне медичне обслуговування населення [4, с.144];

в) спроможність інститутів освіти забезпечити рівні можливості для професійного росту і розвитку громадян [5, с. 399];

г) дієвість механізмів протидії корупції [6, с.10];

д) створення ефективних інститутів захисту власності і забезпечення рівності економічних можливостей [7, с. 39];

є) вияв толерантності до віросповіданням, до осіб інших конфесій i національності[8, с.144];

ж) дотримання верховенства закону, що захищається незалежною судовою владою [9, с. 477];

3) дієвість механізмів об'єктивного висвітлення проблем суспільства i вираження відмінних позицій через відповідні інформаційні ресурси [10, c.188].

Метою статті $є$ здійснити аналіз особливостей реалізації публічної політики в умовах розгортання сучасної пандемії та їі впливу на суспільний розвиток держави.

Виклад основного матеріалу. Публічна політика має перетворитись на «своєрідний індикатора якості інституційного середовища політичної системи, показуючи, наскільки глибоко і органічно в ній представлений демократичний початок... і що дуже важливо емпірично вміти виявляти якість інститутів цієї публічної взаємодії» [1, с. 29]. 3 огляду на це, акцентуючи увагу на особливостях реалізації публічної політики у сфері протидії пандемії доцільно вказати на потенціал держави зберегти потенційну спроможність інститутів публічної політики належно реагувати на виклики пандемії. Слідуючи цьому, ефективність інститутів публічної політики проявляється через їх здатність радикальної трансформації 
відповідно до функціональних вимог, які висуває перед ними відповідна епідеміологічна ситуація.

Варто відзначити, що в умовах пандемії формується «новий узагальнений показник - самодостатності інститутів публічної політики» на підставі якого визначається можливість та конструктивність їх щодо протидії ризикам даного процесу. На думку Х.Дж.Фредеріксона даний показник $\epsilon$ «інструментом для кількісної оцінки та моніторингу стану публічної політики в державі, який будується на основі показників, які характеризують стан суб'єктів публічної сфери та стан розвитку інститутів та механізмів публічної політики» [2]. Відповідний індекс самодостатності публічної політики відповідно до даної концепції будується на двох складових, які визначають якість публічної політики в умовах пандемії. До них належить:

1) ЯН-індекс розвиненості суб'єктів публічної політики (оцінює розвиненість суб'єктів публічної сфери - представницької і виконавчої влади, НКО-сектора, бізнесу, партій, профспілок та ін.);

2) ЯН-індекс, що характеризує стан інституційної інфраструктури публічної політики (ступінь відкритості та демократичності ключових інститутів державного управління; процедури, які стосуються систем i каналів участі громадян у публічній політиці, таких як вибори, верховенство закону, можливості ведення економічної діяльності, цивільний контроль та ін.) $[3$, с.251].

Наведені два індекси дозволяють визначити спроможність публічної політики належно реагувати на ситуація обумовлену ризиками пандемії, а також оцінити результативність механізмів публічної політики. Запровадження даної індексної методології у такий спосіб, дозволяє визначити спроможність інститутів публічної політики належно реагувати на відповідну епідеміологічну ситуацію, ефективно здійснюючи механізми публічного управління.

Аналізуючи особливості реалізації публічної політики в умовах пандемії окрему увагу також варто приділити огляду політичних цінностей та їх впливу на формування публічної діяльності у сфері протидії пандемії. Це відповідним чином, дозволить артикулювати нормативність регулювання процесів формування та реалізації публічної політики в умовах пандемії на їі впливу на деконструкцію методології їі здійснення. У зв'язку із цим звертає на себе увагу ціннісна складова на основі якої і відповідно до якої має розроблятись i здійснюватися публічна політика та реалізовуватись технологічний інструментарій публічного управління. це ставить питання про зміну базових адміністративних цінностей, їх деконструкцію в умовах пандемії і те наскільки вони спроможні демонструвати свою самодостатність 3 огляду на досягнення результативності реалізації протиепідеміологічних заходів. У підтвердження цього Дж.Гоу вказав на те, що в сучасних постмодерних умовах на які припадає виникнення сучасної епідеміологічної ситуації відбувається своєрідна соціальна каузальність відповідно до якої «більшість правил, заснованих на цінностях, ігнорується, етичний режим перетворюється в дисципліну, в норми кримінального та адміністративного 
покарання» [13]. У такий спосіб на думку вченого відбувається методологічна підміна етики цінностей над дисциплінарною етикою, яка грунтується на необхідності запровадження відповідних санкцій, які виявляються найбільш результативними. За відповідних умов виникає необхідність доцільності запровадження відповідного реформаційного підходу до оновлення системи публічного управління у сфері соціальної безпеки, що включає оптимізацію системи охорони здоров'я та системи освіти.

Актуалізація ціннісного наповнення публічної політики в умовах пандемії також лежить в площині моральної мотивації людей, це свідчить про те, що не лише держава задає моральні та правові імперативи дотримання карантинних умов, але й сам громадянин керуючись відповідною моральною шкалою створює відповідні самообмежувальні запобіжники, які слугують пом'якшення протікання пандемії. У даному відношенні громадяни керуючись своєю ціннісною шкалою оцінюють результативність публічної політики щодо реалізації їх соціально безпекових потреб. У даному відношенні йдеться про формування відповідних «етичних режимів», які індикативні сфері реалізації публічної політики в умовах пандемії. Такий контексті свідчить про запровадження відповідної нормативної системи відповідно до якої має формуватися та реалізовуватись публічна політика в умовах відповідний ситуацій об'єктивної невизначеності, до яких і належить пандемія.

Висновки $з$ даного дослідження і перспективи подальших розвідок у даному напрямку. 3 огляду із врахування наведених вище показників результативність реалізації публічної політики в умовах пандемії доцільно вказати на основні вимоги, яким має відповідати ефективна діяльність інститутів публічної політики. До них на думку О. Мак Світа належать:

1) наявність нормативно-правових актів, які регулюють створення інституту, а також визначають правила, норми i процедури його функціонування;

2) відповідність правозастосовної практики в діяльності інституту визначених нормативно-правовими актами;

3) наявність навченого персоналу, який забезпечує якісну роботу інституту публічної політики і відповідає за дотримання його функцій;

4) розуміння громадянами ролі інституту публічної політики і своєї участі в його діяльності (при оцінюванні) [11].

Дотримання відповідних вимог результативності реалізації публічної політики дозволяє виявити показники забезпечення сталості суспільного розвитку та індикатори необхідності запровадження інституціонального реформування у системі публічного управління. Такий підхід свідчить про запровадження горизонтальної інтеграції між відповідними інститутами покликаними забезпечити реалізацію публічної політики в умовах пандемії. В даному відношенні доцільно звернути увагу також i на той факт, що в умовах пандемії «перетворення інститутів соціально-політичної сфери має відбуватись не ізольовано від публічної сфери та соціально-політичних 
акторів, а, навпаки, в тісній взаємодії з просуванням інтересів і очікувань основних агентів публічного поля в державі, зацікавлених в ефективному функціонуванні даних інститутів» [12].

Висновки. Здійснений нами аналіз особливостей реалізації публічної політики в умовах розгортання сучасної пандемії та її впливу на суспільний розвиток держави дозволив розкрити основні умови, фактор та тенденції поширення пандемії коронавірусної інфекції COVID-19, охарактеризовано трансформацію інституційної вертикалі публічної політики у напрямку готовності забезпечити відкритість публічного управління у сфері протидії пандемії, забезпечення сталості функціонування сфери охорони здоров'я та ін.; запропоновано необхідність розроблення «нового узагальненого показника - самодостатності інститутів публічної політики» на підставі якого визначається можливість та конструктивність їх щодо протидії ризикам пандемії; наведено індикатори результативності механізмів публічного контролю за діяльністю інститутів публічної політики, покликаних забезпечити запровадження антиепідеміологічних заходів; показано сутність ціннісного наповнення публічної політики в умовах пандемії, відповідно до чого громадянин керуючись певною моральною шкалою створюють відповідні самообмежувальні запобіжники, які слугують пом'якшенню протікання пандеміі; встановлено, що реалізація публічної політики в умовах пандемії має набути нових інституціональних стимулів, аби вивести діяльність іiі інститутів держави із «механічної, безособової та реакційної системи», неспроможності демонструвати результативність індикативних стратегій сталого розвитку суспільства.

\section{Jimepamypa:}

1. Aucoin Peter. A profession of public administration? A commentary on a Strong Foundation, Canadian Public Administration, 1997, 40:1, p. 25-39.

2. Frederickson H. George (ed). Ethics and Public Administration, 1993. URL: https://www.jstor.org/stable/1047757?seq=1

3. Stewart Debra and Sprinthall, Norman A. Strengthening Ethical Judgement in publi Administration, in J.S Bowman (ed.) 1991, p. 243-260.

4. Dwivedi O.P.et Gow J.I. From Bureaucracy to Public Management. The Administrative Culture of the Government of Canada, Peterborough, Broadview Press, 1999.

5. Cooper Terry L. Big questions in administrative ethics : A need for focused, collaborative effort. Public Administration Review, 2004, № 64:4, p. 395-407.

6. Hood Christopher. A public management for all seasons? Public Administration, 1991, № 69:1, p. 3-19.

7. Frederickson H. George. Research and knowledge in administrative ethics, in T.L. Cooper (ed.) 1994, p. 31-47.

8. Rohr John A. Ethics for Bureaucrats. An Essay on Law and Values. 2d ed. New York, Marcel Dekker, 1989.

9. Boisvert Yves. L'imiginaire éthique des répondants du réseau gouvernemental québécois en matière d'éthique, Canadian Public Administration, 2004, №47:4, p. 475-496

10. Paquet Gilles. Governance Through Social Learning (Ottawa, Presses de l'Université d'Ottawa), 1999.

11. McSwite O.C. Legitimacy in Public Administration, Thousand Oaks CA, Sage, 1997. URL: https://www.jstor.org/stable/2666989?seq=1 
12. Harmon Michael. Responsibility as Paradox. A Critique of Rational Discourse on Government. (Thousand Oaks CA, Sage), 1995. URL: https://catalogue.nla.gov.au/Record/2189803

13. Gow J.I. A Practical Basis for Public Service Ethics. Paper prepared for the annual conference of Canadian Political Science Association Western University, London Ontario, 2005. URL: http://www.cpsa-acsp.ca/papers-2005/Gow.pdf

\section{References:}

1. Aucoin, Peter (1997). A profession of public administration? A commentary on A Strong Foundation, Canadian Public Administration [in English].

2. Frederickson, H. George (ed) (1993). Ethics and Public Administration. Retrieved from https://www.jstor.org/stable/1047757?seq=1 [in English]

3. Stewart, Debra and Sprinthall, Norman A. (1991). Strengthening Ethical Judgement in publi Administration [in English].

4. Dwivedi, O.P.et Gow, J.I. (1999). From Bureaucracy to Public Management. The Administrative Culture of the Government of Canada. Broadview Press [in English].

5. Cooper, Terry L. (2004). Big questions in administrative ethics : A need for focused, collaborative effort. Public Administration Review [in English].

6. Hood, Christopher (1991). A public management for all seasons? Public Administration [in English].

7. Frederickson, H. George (1994). Research and knowledge in administrative ethics, in T.L. Cooper (ed.) [in English].

8. Rohr, John A. (1989). Ethics for Bureaucrats. An Essay on Law and Values. 2d ed. New York, Marcel Dekker [in English].

9. Boisvert, Yves (2004). L'imiginaire éthique des répondants du réseau gouvernemental québécois en matière d'éthique. Canadian Public Administration [in English].

10. Paquet, Gilles (1999). Governance Through Social Learning. Ottawa, Presses [in English].

11. McSwite, O.C (1997). Legitimacy in Public Administration. Thousand Oaks CA, Sage. Retrieved from: https://www.jstor.org/stable/2666989?seq=1 [in English].

12. Harmon, Michael (1995). Responsibility as Paradox. A Critique of Rational Discourse on Government. Retrieved from https://catalogue.nla.gov.au/Record/2189803 [in English].

13. Gow, J.I. (2005). A Practical Basis for Public Service Ethics. Paper prepared for the annual conference of Canadian Political Science Association Western University, London Ontario. Retrieved from: http://www.cpsa-acsp.ca/papers-2005/Gow.pdf [in English]. 